\title{
BĖGIMO PALENGVINTOMIS SĄLYGOMIS POVEIKIS SKIRTINGO MEISTRIŠKUMO SPORTININKIŲ BËGIMO TECHNIKAI
}

\author{
Danguolė Satkunskiené $\dot{1}^{1,2}$, Donatas Rauktys ${ }^{2}$ \\ Kauno technologijos universitetas ${ }^{1}$, Lietuvos kūno kultūros akademija ${ }^{2}$, Kaunas, Lietuva
}

\begin{abstract}
Danguolė Satkunskienė. Docentė socialinių mokslų daktarė. Lietuvos kūno kultūros akademijos Sporto edukologijos fakulteto dekanė, Kauno technologijos universiteto Inžinerinès mechanikos katedros vyresnioji mokslo darbuotoja. Mokslinių tyrimų kryptis — žmogaus judesių biomechanikos tyrimai, sportininkų techninio rengimo modeliavimas.
\end{abstract}

\section{SANTRAUKA}

Tyrimo tikslas - nustatyti bègimo palengvintomis salygomis poveiki skirtingo meistriškumo sportininkiu bègimo technikai. Tirtos trys didelio meistriškumo sportininkès, kuriu 200 m bégimo rezultatas buvo nuo 23,86 iki 25,33 s (amžius 20-26 m.; ügis 167-173 cm; küno mase 59-65 kg) ir trys mažesnio meistriškumo sportininkès, kuriu $200 \mathrm{~m}$ bëgimo rezultatas - пио 27,54 iki 27,68 s (amžius 13-15 m.; ügis 168-171 cm; svoris 50-53 kg). Tiriamosios bègo šešis kartus po 30 metru iš vietos, bègima pradedamos iš aukštos pradmès. Paskutinius tris kartus bègikès buvo tempiamos standžia guma. Po kiekvieno bègimo sportininkès ilsèjosi nuo 5 iki 7 minučiu. Bègimas buvo filmuojamas skaitmenine CANON XM1 vaizdo kamera iš šono 20-30-ame bégimo metre. Bègimo technikos analizè atlikta naudojant specializuota judesiu analizès programa SIMI MOTION 2D. Apskaičiuota: atramos trukmé, žingsnio ilgis, bégimo tempas, klubo sqnario momentinis kampas ir kampinis greitis viso ciklo metu. Buvo analizuojamas maksimalus šlaunies lenkimo kampas mosto metu, šlaunies kampas su vertikale kojos pastatymo bei atitraukimo momentu, maksimalusis šlaunies tiesimo greitis kojos pastatymo momentu ir maksimalusis šlaunies tiesimo greitis atramos metu.

Palyginus skirtingo meistriškumo sportininkiu bègimo kinematinius rodiklius bègant natüraliai maksimaliuoju greičiu ir bègant palengvintomis salygomis (tempiant standžia guma), buvo nustatyti statistiškai patikimi kinematiniu rodikliu

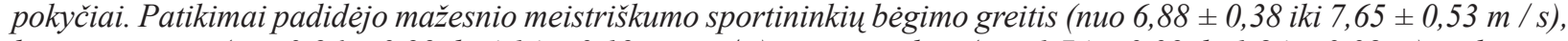
bègimo tempas (nиo 3,96 \pm 0,22 iki 4,14 $\pm 0,19$ žings. / s), žingsnio ilgis (nuo 1,74 0,09 iki 1,84 $\pm 0,08 \mathrm{~m}$ ) ir šlaunies tiesimo greitis kojos pastatymo ant atramos momentu (nuo 4,70 $\pm 0,78$ iki 6,40 $\pm 1,3 \mathrm{rad} / \mathrm{s}$ ); sumažéjo atramos trukmé (nиo 0,11 $\pm 0,01$ iki 0,10 $\pm 0,01$ s) ir šlaunies lenkimo kampas statant kojq ant atramos (nuo 31,39 $\pm 4 \mathrm{iki} 27,35 \pm 2,6^{\circ}$ ). Patikimai padidèjo didesnio meistriškumo sportininkiu bègimo greitis (nиo 8,21 $\pm 0,61 \mathrm{iki} 9,21 \pm 0,68 \mathrm{~m} / \mathrm{s}$ ), žingsnio ilgis (nиo 1,94 $\pm 0,06$ iki 2,14 $\pm 0,07 \mathrm{~m}$ ) ir maksimalusis šlaunies tiesimo greitis atramos metu (nиo 9,63 $\pm 0,4 \mathrm{iki}$

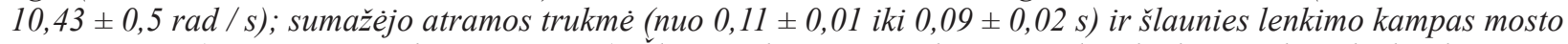
pirmyn mеtu (пио 64,62 \pm 4 iki 59,27 $\pm 3,2^{\circ}$ ). Šlaunies kampinio judejimo analizé leido pastebèti, kad palengvintu bègimo salygu taikymas didesnio meistriškumo sprinterèms neturèjo reikšmingos ìtakos labiausiai greitị limituojančiam bègimo technikos elementui - šlaunies tiesimo greičiui kojos pastatymo ant atramos momentu.

Raktažoď̌iai: sprintas, kinematiniai rodikliai, palengvintos salygos, meistriškumas.

\section{IVADAS}

$\mathrm{P}$ asaulio ir Lietuvos elito sprinterių bėgimo žingsnio kinematinių rodiklių lyginamoji analizè leido nustatyti Lietuvos bėgikių greiti limituojančius veiksnius: per didelis šlaunies lenkimo kampas atremties fazès pradžioje, kelio lenkimo kampas amortizacijos fazèje, šlaunies ir blauzdos tiesimo amplitude atsispyrimo metu (Satkunskienè, Stanislovaitis, 2004).

D. E. Deshon ir R. C. Nelson (1963), H. Kunz ir D. A. Kaufmann (1981), R. Mann ir J. Herman (1985) nustatè, kad didelio meistriškumo sprin- teriai, statydami pėdą ant atramos arčiau kūno masès centro projekcijos (mažas šlaunies lenkimo kampas atremties fazès pradžioje), gali anksčiau pradèti aktyviai tiesti šlauni, sumažinti amortizacijos fazę ir neigiamą greičio pokyti (Mero, 1988). Aktyvus šlaunies tiesimas atremties pradžioje yra labai svarbus norint padidinti varomąsias jègas (Wood, 1987).

Per didelis kelio lenkimo kampas amortizacijos fazeje suaktyvina kelio tiesimą atsispyrimo metu (didina blauzdos tiesimo amplitudę). 
M. D. Johson ir J. G. Buckley (2001) nustatè, kad kelio tiesimas atsispyrimo pabaigoje nèra efektyvus, norint tuo metu padidinti sportininko greitį. M. Čoh ir A. Dolenec (2002) teigia, kad statant pedą ant atramos koja turi būti standi, kuo mažiau linkti per kelio sąnari. Nustatytas vidutinio stiprumo statistinis ryšys tarp blauzdos lenkimo amplitudès amortizacijos fazeje ir bègimo rezultato rodo neigiamą kelio lenkimo poveiki bėgimo greičiui (Čoh, Dolenec, 2002; Satkunskienè, Stanislovaitis, 2004).

Kitas svarbus Lietuvos bėgikiu greiti limituojantis veiksnys yra per didelis šlaunies tiesimo kampas atsispyrimo pabaigoje. Didinti šlaunies tiesimo kampą atsispyrimo pabaigoje yra neefektyvu, nes šlaunies tiesiamieji raumenys aktyviausi amortizacijos fazeje (Man, Spraque, 1980; Mann, 1981; Johson, Buckley, 2001), o blauzdos tiesiamieji atsispyrimo metu sukuria palyginti nedideli galingumą (Johson, Buckley, 2001).

Norint pagerinti Lietuvos sprinteriu bėgimo technika, būtina parinkti tokius pratimus, kurie skatintų statyti pėdą arčiau kūno masès centro projekcijos, didintu šlaunies tiesimo greiti amortizacijos fazeje (didintų šlaunies tiesiamujų raumenų aktyvumą atramos pradžioje), mažintų kelio lenkimo kampą amortizacijos fazèje ir tiesimo kampa atsispyrimo metu (stiprintu blauzdos tiesiamujų ir pèdos lenkiamujų raumenų ekscentrinio susitraukimo jègą).

Lavinant sprinterių greitumą, dažniausiai naudojami dviejų rūšių pratimai: bėgimas palengvintomis sąlygomis (nuo kalno, tempiant guma, ant bėgimo takelio greičiu, didesniu už maksimaluji bėgiko greiti) ir bėgimas su pasipriešinimu (i kalną, su svoriais, tempiant parašiutą). Nors šie pratimai plačiai naudojami daugelį metų, jų efektyvumas pradètas tirti gana neseniai.

A. Knicker (1997) ištyrè išorinès apkrovos poveiki bègimo mechanikai ir nustate, kad netgi mažos apkrovos reikšmingai keičia bėgimo kinematinius rodiklius ir raumenu veiklos koordinaciją. Autorius pabrèžè, kad bègimas su pasipriešinimu buvo ,panašus, tačiau ne identiškas“ bègimui isibègejjimo (pagreitejjimo) atkarpoje. R. J. Corn ir D. Knudson (2003) nustate, kad tempiant sportininką tampria virve ísibègejjimo metu reikšmingai padidèja bėgimo greitis, žingsnio ilgis bei sumažeja atstumas tarp pėdos ir kūno masès centro projekcijos. A. Mero ir P. V. Komi (1987) raumenu elektrinio aktyvumo bei atramos reakcijos jègos bėgant sub- ir supermaksimaliuoju greičiu tyrimai parodè, kad bėgant supermaksimaliuoju greičiu (tempiant sportininkus) reikšmingai padidejo raumenų aktyvumas prieš pat kojos pastatymą bei atramos reakcijos jèga kojos pastatymo momentu, tačiau atsispyrimo metu nei raumenu aktyvumas, nei atramos reakcijos jèga patikimai nesiskyrè nuo bėgimo submaksimaliuoju greičiu. J. S. LeBlanc ir P. L. Gervais (2004) atliko vyru sprinteriu bègimo kinematiniu rodiklių pokyčio analizę bègant natūraliai, palengvintomis ir pasunkintomis sąlygomis įsibègejjimo ir maksimalaus bejgimo metu. J. S. LeBlanc ir P. L. Gervais nenustate patikimo skirtumo tarp natūralaus bėgimo maksimaliuoju greičiu ir bègimo palengvintomis sąlygomis. Tenka pastebèti, kad bėgimo technikos pokyčių tyrimai apsiribojo tik kelių rodikliu palyginimu: bėgimo greičio, atramos trukmès, žingsnio ilgio, bėgimo tempo, liemens pasvyrimo kampo bei šlaunies ir blauzdos judesių amplitudès, todèl vargu ar galima teigti, kad bègimas palengvintomis sąlygomis visiškai nekeičia bėgimo technikos.

Tempiant sportininką standžia guma, jis igyja papildomos kinetinès energijos, kurios realizavimas priklauso nuo kojų judesių greitumo. Manome, kad nuodugni skirtingo meistriškumo sprinterių kojų judesių analizè padètu geriau suprasti begimo palengvintomis sąlygomis poveiki bėgimo technikai priklausomai nuo sportininku meistriškumo.

Tyrimo tikslas - nustatyti bėgimo palengvintomis sąlygomis poveiki skirtingo meistriškumo sportininkių bėgimo technikai.

\section{TYRIMO METODAI}

Tiriamieji. Tirtos trys didelio meistriškumo sportininkès (DM), kurių $200 \mathrm{~m}$ bėgimo rezultatas buvo nuo 23,86 iki 25,33 s (amžius 20-26 m.; ūgis $167-173 \mathrm{~cm}$; kūno masè $59-65 \mathrm{~kg}$ ) ir trys mažesnio meistriškumo sportininkès (MM), kurių $200 \mathrm{~m}$ bėgimo rezultatas - nuo 27,54 iki 27,68 s (amžius 13-15 m.; ūgis $168-171 \mathrm{~cm}$; kūno mase $50-53 \mathrm{~kg}$ ).

Filmavimas. Bègimas buvo pradedamas iš aukštos pradmès ir filmuojamas skaitmenine CANON XM1 vaizdo kamera iš šono 20-30-ame bėgimo metre. Vaizdo kamera buvo nukreipta statmenai i begimo takeli. Nufilmuotas vaizdas naudojant SIMI MOTION kompiuterinę programą iš kameros buvo perkeltas i kompiuterị. Vaizdų perkèlimo diskretiškumas $-0,02 \mathrm{~s}$. 
1 pav. Sportininkių tempimo schema

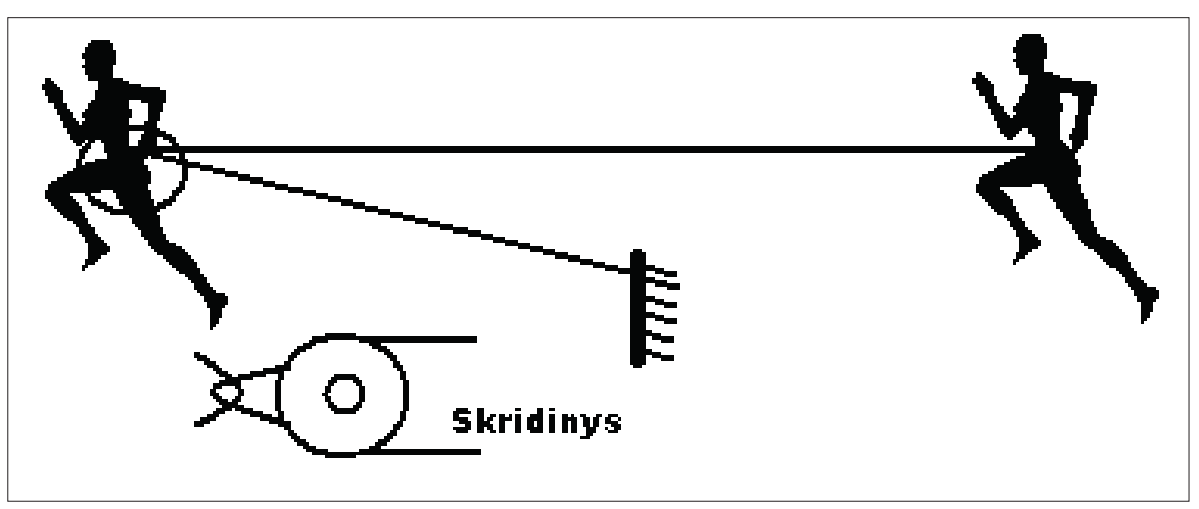

2 pav. Šlaunies maksimalus lenkimo kampas mosto metu (a), kojos pastatymo (b) ir atitraukimo (c) nuo atramos momentu

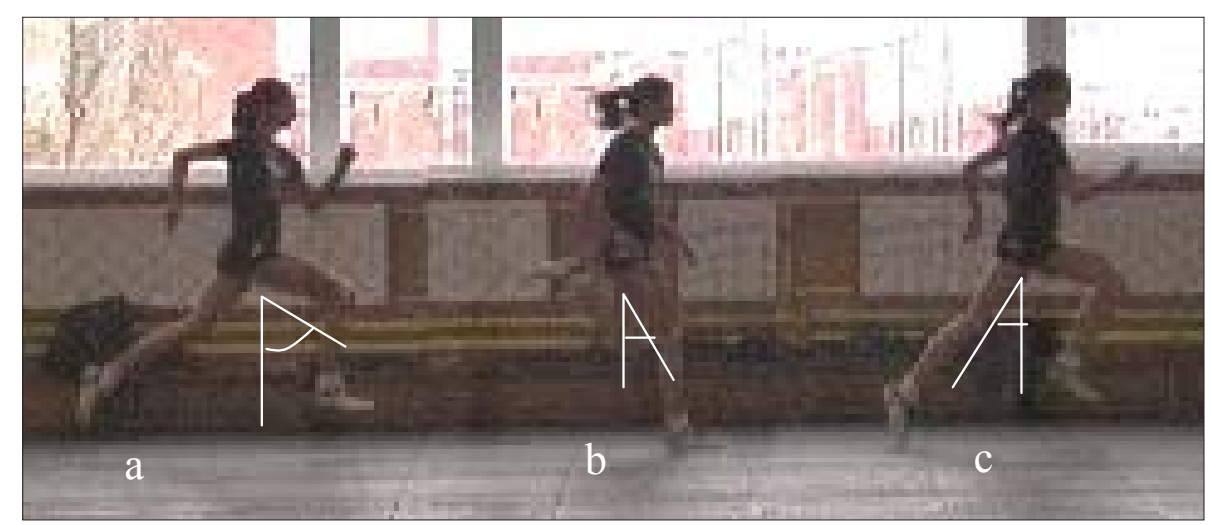

Vidutinis bėgimo greitis buvo apskaičiuotas pagal formulę: $\mathrm{V}=\mathrm{L} / \mathrm{t}_{\text {ciklo }}$ (čia $\mathrm{L}$ - bègimo ciklo ilgis - atstumas nuo kairès pédos pirštų atramos metu iki kitos atramos kaire koja pėdos pirštų; $\mathrm{t}_{\text {ciklo }}$ - ciklo trukmè - laiko intervalas nuo kairès kojos atramos pradžios iki kitos atramos pradžios kaire koja). Atramos pradžia - tai laiko momentas, kai pèda paliečia atramą. Bègimo ciklo ilgis ir trukmé buvo nustatyti naudojant SIMI MOTION Still Mode programa.

Tiriamosios bègo šešis kartus po 30 metru iš vietos, bejgimą pradėdamos iš aukštos pradmès. Paskutinius tris kartus bėgikès buvo tempiamos standžia guma. Tempimo schema pateikta 1 paveiksle. Po kiekvieno bėgimo sportininkès ilsèjosi nuo 5 iki 7 minučiu.

Bėgimo technikos analizè buvo atlikta naudojant specializuotą judesių analizès programą SIMI MOTION 2D. Šia programa iš nufilmuoto vaizdo apskaičiuoti žingsnio kinematiniai rodikliai: atramos trukmè, žingsnio ilgis, bėgimo tempas, klubo sąnario momentinis kampas ir kampinis greitis viso ciklo metu. Buvo analizuojamas maksimalus šlaunies lenkimo kampas mosto metu ( 2 a pav.), šlaunies kampas su vertikale kojos pastatymo ( 2 b pav.) ir atitraukimo momentu ( 2 c pav.), maksimalusis šlaunies tiesimo greitis kojos pastatymo momentu ir maksimalusis šlaunies tiesimo greitis atramos metu.
Matematinè statistika. Skaičiavimai buvo atliekami naudojantis programos „Microsoft Excel" statistiniu paketu Data Analysis. Apskaičiuotas aritmetinis vidurkis, standartinis nuokrypis. Aritmetinių vidurkių skirtumo patikimumas nustatytas naudojant Stjudento $t$ kriterijų. Vertinant patikimumą, imamas reikšmingumo lygmuo $\mathrm{p}<0,05$ (95\% patikimumas).

\section{REZULTATAI}

Bègimo palengvintomis sąlygomis poveikis mažesnio meistriškumo sportininkių bėgimo technikai. Mažesnio meistriškumo sportininkių bėgimo žingsnio kinematiniai rodikliai bėgant natūraliomis sąlygomis maksimaliuoju greičiu ir tempiant guma pateikti 1 ir 2 lenteleje. Bejgant palengvintomis sąlygomis (tempiant sportininkes guma), patikimai $(\mathrm{p}<0,05)$ padidejo bėgimo greitis, bègimo tempas, žingsnio ilgis ir sumažèjo atramos trukmè (1 lent.).

Tempiant guma patikimai $(\mathrm{p}<0,05)$, sumažèjo šlaunies lenkimo kampas statant koją ant atramos, tačiau šiek tiek padidejo šlaunies tiesimo kampas atsispyrimo pabaigoje. Todèl klubo sąnario judejjimo amplitudè atramos metu pakito nedaug (atitinkamai nuo 49,06 $\pm 6,6$ iki 45,58 $\pm 6,0^{\circ}$ ). Bègant palengvintomis sąlygomis, truputi padidejo šlaunies lenkimo kampas mosto pirmyn metu ir 


\begin{tabular}{|l|c|c|c|c|c|}
\hline \multicolumn{1}{|c|}{ Bègimas } & $\begin{array}{c}\text { Bègimo } \\
\text { greitis, } \mathrm{m} / \mathrm{s}\end{array}$ & $\begin{array}{c}\text { Atramos } \\
\text { trukmé, } \mathrm{s}\end{array}$ & $\begin{array}{c}\text { Polëkio } \\
\text { trukmè, } \mathrm{s}\end{array}$ & $\begin{array}{c}\text { Žingsnio ilgis, } \\
\mathrm{m}\end{array}$ & $\begin{array}{c}\text { Tempas, } \\
\text { žings. / s }\end{array}$ \\
\hline Natūralus bėgimas & $6,88 \pm 0,38$ & $0,11 \pm 0,01$ & $0,14 \pm 0,01$ & $1,74 \pm 0,09$ & $3,96 \pm 0,22$ \\
\hline Tempiant guma & $7,65 \pm 0,53$ & $0,10 \pm 0,01$ & $0,14 \pm 0,01$ & $1,84 \pm 0,08$ & $4,14 \pm 0,19$ \\
\hline $\mathrm{p}$ & $<0,05$ & $<0,05$ & $>0,05$ & $<0,05$ & $<0,05$ \\
\hline
\end{tabular}

\begin{tabular}{|l|c|c|c|c|c|}
\hline \multirow{2}{*}{ Bègimas } & \multicolumn{2}{|c|}{ Šlaunies kampas su vertikale, laipsniai } & \multicolumn{2}{c|}{ Šlaunies tiesimo greitis, rad / s } \\
\cline { 2 - 6 } & $\begin{array}{c}\text { Atramos } \\
\text { pradžia }\end{array}$ & $\begin{array}{c}\text { Atramos } \\
\text { pabaiga }\end{array}$ & $\begin{array}{c}\text { Maksimalus } \\
\text { mosto metu }\end{array}$ & Atramos pradžia & $\begin{array}{c}\text { Maksimalusis } \\
\text { atramos metu }\end{array}$ \\
\hline Natūralus bėgimas & $31,39 \pm 4$ & $-16,89 \pm 8,5$ & $59,65 \pm 3,1$ & $4,70 \pm 0,7$ & $8,39 \pm 1,1$ \\
\hline Tempiant guma & $27,35 \pm 2,6$ & $-18,24 \pm 4,1$ & $61,25 \pm 3,2$ & $6,40 \pm 1,3$ & $8,62 \pm 0,9$ \\
\hline $\mathrm{p}$ & $<0,05$ & $>0,05$ & $>0,05$ & $<0,05$ & $>0,05$ \\
\hline
\end{tabular}

1 lentelè. Mažesnio meistriškumo sportininkių kinematiniai bègimo žingsnio rodikliai bėgant natūraliomis sąlygomis ir tempiant guma

\begin{tabular}{|l|c|c|c|c|c|}
\hline \multicolumn{1}{|c|}{ Bègimas } & $\begin{array}{c}\text { Bègimo greitis, } \\
\mathrm{m} / \mathrm{s}\end{array}$ & $\begin{array}{c}\text { Atramos } \\
\text { trukmé, } \mathrm{s}\end{array}$ & $\begin{array}{c}\text { Polékio } \\
\text { trukmé, } \mathrm{s}\end{array}$ & $\begin{array}{c}\text { Žingsnio } \\
\text { ilgis, } \mathrm{m}\end{array}$ & $\begin{array}{c}\text { Tempas, } \\
\text { žings. / s }\end{array}$ \\
\hline Natūralus bėgimas & $8,21 \pm 0,61$ & $0,11 \pm 0,01$ & $0,13 \pm 0,02$ & $1,94 \pm 0,06$ & $4,23 \pm 0,39$ \\
\hline Tempiant guma & $9,21 \pm 0,68$ & $0,09 \pm 0,02$ & $0,14 \pm 0,01$ & $2,14 \pm 0,07$ & $4,32 \pm 0,40$ \\
\hline $\mathrm{p}$ & $<0,05$ & $<0,05$ & $>0,05$ & $<0,05$ & $>0,05$ \\
\hline
\end{tabular}

2 lentelè. Mažesnio meistriškumo sportininkių šlaunies lenkimo ir tiesimo kampai, kampiniai greičiai kojos pastatymo, atitraukimo momentais ir mosto metu, bègant natūraliomis sąlygomis ir tempiant guma

\begin{tabular}{|l|c|c|c|c|c|}
\hline \multirow{2}{*}{ Bègimas } & \multicolumn{2}{|c|}{ Šlaunies kampas su vertikale, laipsniai } & \multicolumn{2}{c|}{ Šlaunies tiesimo greitis, rad / s } \\
\cline { 2 - 6 } & $\begin{array}{c}\text { Atramos } \\
\text { pradžia }\end{array}$ & $\begin{array}{c}\text { Atramos } \\
\text { pabaiga }\end{array}$ & $\begin{array}{c}\text { Maksimalus } \\
\text { mosto metu }\end{array}$ & $\begin{array}{c}\text { Atramos } \\
\text { pradžia }\end{array}$ & $\begin{array}{c}\text { Maksimalusis } \\
\text { atramos metu }\end{array}$ \\
\hline Natūralus bėgimas & $35,42 \pm 3,5$ & $-24,01 \pm 4,6$ & $64,62 \pm 4$, & $6,74 \pm 0,8$ & $9,63 \pm 0,4$ \\
\hline Tempiant guma & $31,99 \pm 5,8$ & $-20,71 \pm 6,2$ & $59,27 \pm 3,2$ & $7,20 \pm 1,3$ & $10,43 \pm 0,5$ \\
\hline $\mathrm{p}$ & $>0,05$ & $>0,05$ & $<0,05$ & $>0,05$ & $<0,05$ \\
\hline
\end{tabular}

3 lentelè. Didesnio meistriškumo sportininkių kinematiniai bègimo žingsnio rodikliai bėgant natūraliomis sąlygomis ir tempiant guma

maksimalusis šlaunies kampinis greitis atramos momentu.

Bėgimo palengvintomis sąlygomis poveikis didesnio meistriškumo sportininkių bègimo technikai. Didesnio meistriškumo sportininkiu bègimo technikos pokyčiai bėgant palengvintomis sąlygomis pateikti 3 ir 4 lenteleje. Lenteliu duomenys rodo, kad pratimo metu patikimai padidejo $(\mathrm{p}<0,05)$ bėgimo greitis, žingsnio ilgis ir sumažejo atramos trukmè. Polèkio trukmè šiek tiek padidèjo. Bègimo tempas padidèjo nuo 4,23 $\pm 0,39$ iki 4,32 $\pm 0,40$ žings. / s, tačiau šis skirtumas statistiškai nepatikimas.

Lyginant šlaunies kampini judèjimą (4 lent.) buvo nustatyta, kad bejgant palengvintomis sąlygomis patikimai $(p<0,05)$ sumažèjo šlaunies lenkimo kampas mosto pirmyn metu ir padidejo maksimalusis šlaunies tiesimo greitis atramos metu. Kiti rodiklių pokyčiai taip pat rodo technikos gerejjimo tendenciją: sumažejjo šlaunies lenkimo kampas atramos pradžioje, šlaunies tiesimo kampas atramos pabaigoje ir padidejo šlaunies tiesimo greitis atramos pradžioje.

Skirtingo meistriškumo sportininkių šlaunies kampinis judėjimas bėgant maksimaliuoju greičiu. Skirtingo meistriškumo sportininkiu šlaunies kampinis poslinkis bėgant maksimaliuoju greičiu pavaizduotas 3 paveiksle. Geriausią $200 \mathrm{~m}$ bėgimo rezultatą turinčios sportininkès (DM, 23,86 s) šlaunies lenkimo kampas statant koją ant atramos $\left(35,95^{\circ}\right)$ ir maksimalus šlaunies lenkimo kampas mojant koją pirmyn $\left(64,26^{\circ}\right)$ yra didesnis, lyginant su mažiausio meistriškumo (MM $200 \mathrm{~m}$ rezultatas $-27,54 \mathrm{~s}$ ) sportininkès (atitinkamai 27,61 ir 56,63 ${ }^{\circ}$ ). Šlaunies tiesimo kampas pédos atitraukimo nuo atramos momentu abiejų sportininkių buvo vienodas (apie $17^{\circ}$ ), tačiau kojos mostas atgal buvo $5^{\circ}$ mažesnis didesnio meistriškumo sportininkès: atitinkamai 25,66 ir $31,03^{\circ}$.

Lyginant abieju sportininkiu šlaunies kampinio judejjimo greiti pédos pastatymo momentu (4 pav.) buvo pastebeta, kad DM jis buvo didesnis, lyginant su MM (atitinkamai 7,15 ir 5,77 rad / s). Maksimaluji šlaunies kampinio judejjimo greiti skirtingos sportininkès pasiekè vienodu laiko momentu (nuo atramos pradžios praejjus $0,06 \mathrm{~s}$ ), tačiau DM sportininkès jis buvo didesnis (atitinkamai 9,65 ir 8,55 rad / s). Didesnio meistriškumo sportininkei būdingas didesnis šlaunies lenkimo greitis mosto pirmyn pradžioje ir tolygus šio greičio pokytis viso mosto metu. 
3 pav. Skirtingo meistriškumo sportininkių šlaunies kampinis poslinkis bẻgant maksimaliuoju greičiu

Pastaba. MM - mažiausio meistriškumo sportininke; DM — didžiausio meistriškumo sportininkè.

4 pav. Skirtingo meistriškumo sportininkių šlaunies kampinis greitis bėgant maksimaliuoju greičiu

Pastaba. MM - mažiausio meistriškumo sportininkè; DM — didžiausio meistriškumo sportininkè.

5 pav. Skirtingo meistriškumo sportininkių šlaunies kampinis poslinkis bègant palengvintomis sąlygomis

Pastaba. MM - mažiausio meistriškumo sportininké; DM — didžiausio meistriškumo sportininkè.
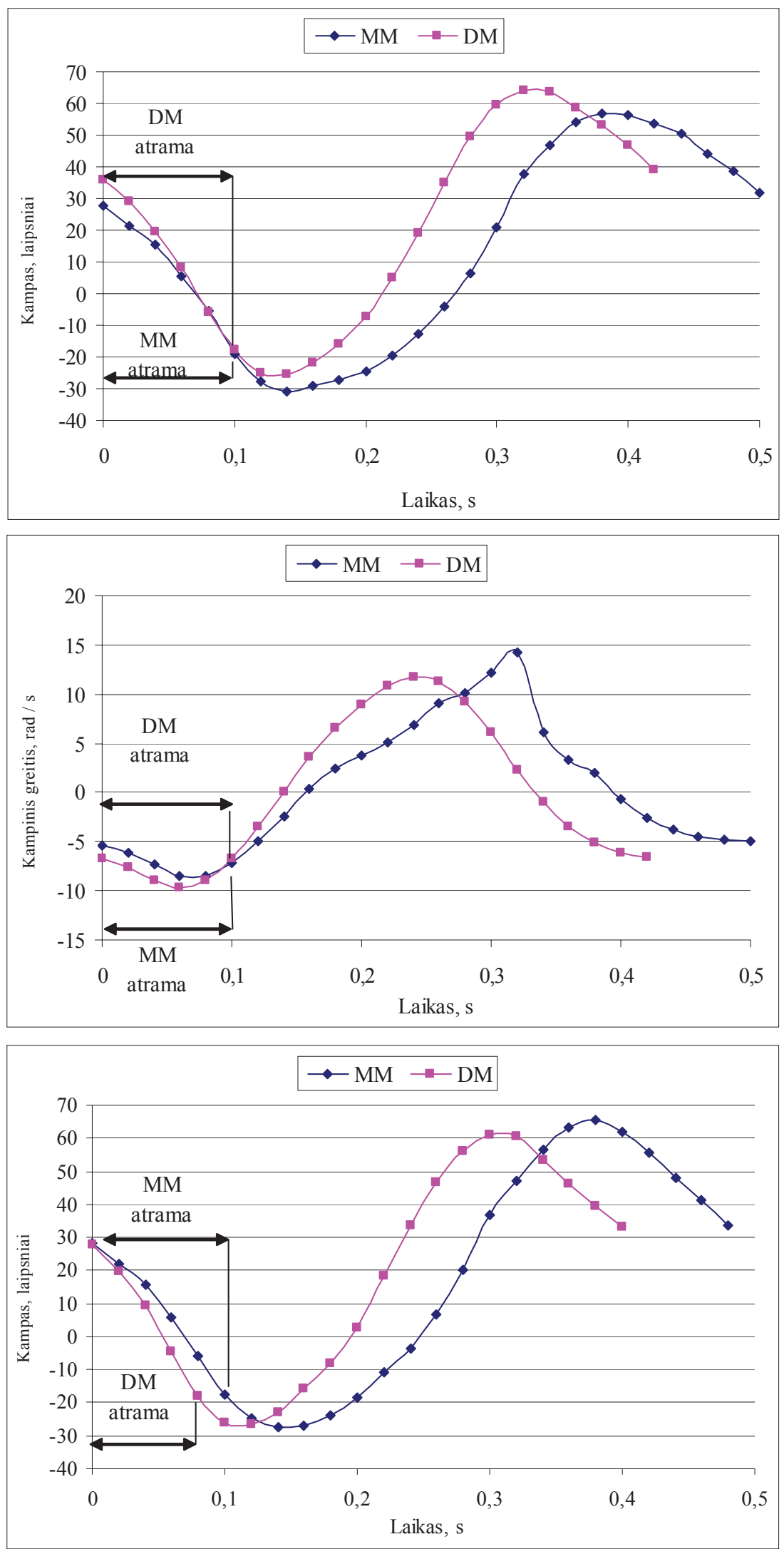

Bègimo palengvintomis sąlygomis poveikis skirtingo meistriškumo sportininkių šlaunies kampiniam judejjimui. Bègant palengvintomis sąlygomis, didesnio meistriškumo sportininkès šlaunies lenkimo kampas kojos pastatyto momen- tu sumažèjo iki $27,77^{\circ}$, o mažesnio - nepakito (5 pav.). Taigi, bejgant palengvintomis sąlygomis, abiejų sportininkių šlaunies lenkimo kampas statant koją ant atramos buvo vienodas. Galima manyti, kad sumažèjęs šlaunies lenkimo kampas 


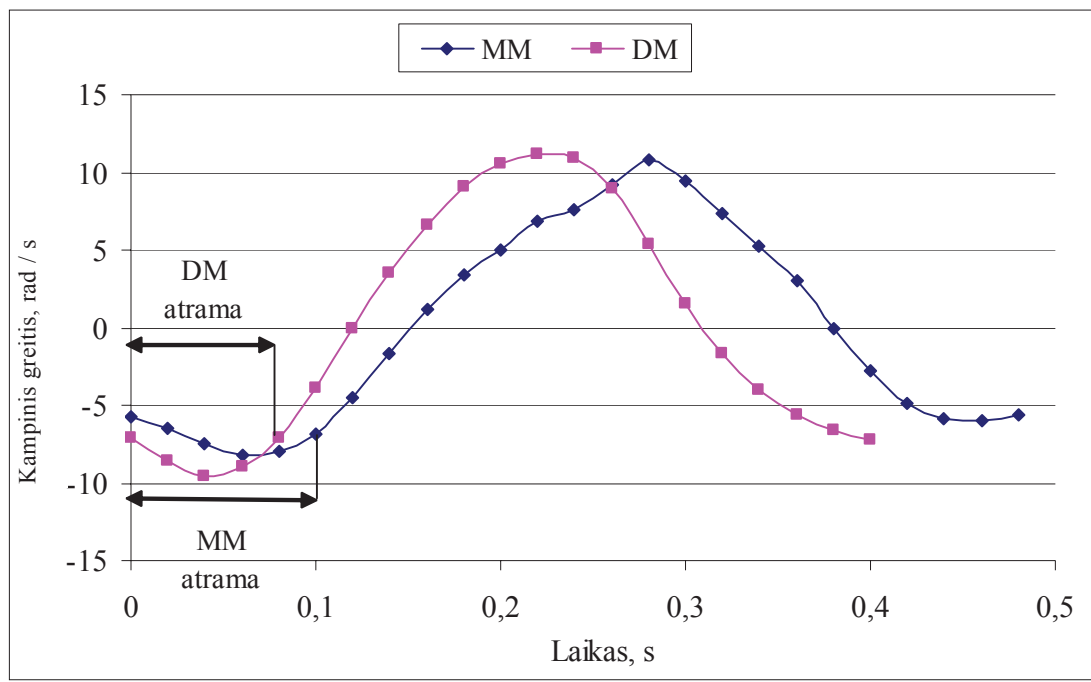

6 pav. Skirtingo meistriškumo sportininkių šlaunies kampinis greitis bėgant palengvintomis sąlygomis kojos pastatymo momentu turejjo įtakos atramos trukmei (DM sportininkès sumažèjo 0,02 s). Tai sumažino ciklo trukmę ir padidino bėgimo tempa nuo 4,76 iki 5 cikl. / s.

Šlaunies tiesimo kampas kojos atitraukimo nuo atramos momentu bėgant palengvintomis sąlygomis abiejų sportininkių nekito, tačiau sumažèjo mažesnio meistriškumo sportininkès šlaunies tiesimo kampas koją mojant atgal.

Maksimalus šlaunies lenkimo kampas mojant koją pirmyn didesnio meistriškumo sportininkès padidejjo, o mažesnio - sumažèjo. Tai sumažino sportininkių rodiklių skirtumą. Taigi galima manyti, kad tempimas guma suvienodino skirtingo meistriškumo sportininkių kojos pastatymo ir mosto techniką.

Skirtingo meistriškumo sportininkių šlaunies kampinis greitis bėgant palengvintomis sąlygomis pavaizduotas 6 paveiksle. Kojos pastatymo momentu šlaunies kampinis greitis DM sportininkès padidèjo nuo 6,77 iki 7,15 rad / s, o MM - nuo 5,37 iki 5,77 rad / s. Maksimalusis šlaunies tiesimo greitis atremties metu sumažèjo abieju sportininkių atitinkamai nuo 9,63 iki 9,51 rad/s ir nuo 8,55 iki 8,17 rad/s. Maksimalusis šlaunies tiesimo greitis didesnio meistriškumo sportininkès buvo pasiektas $0,02 \mathrm{~s}$ anksčiau, nei bėgant maksimaliuoju greičiu, o mažesnio meistriškumo sportininkès maksimalusis šlaunies tiesimo greitis buvo pasiektas tuo pačiu laiko momentu.

\section{REZULTATUQ APTARIMAS}

Lyginant skirtingo meistriškumo sportininkių bėgimo kinetinius rodiklius bėgant maksimaliuoju greičiu ir palengvintomis sąlygomis (tempiant guma), buvo nustatyti statistiškai patikimi pokyčiai, saviti skirtingose meistriškumo grupėse. Patikimai padidèjo mažesnio meistriškumo sportininkių bėgimo greitis, bėgimo tempas, žingsnio ilgis bei šlaunies tiesimo greitis kojos pastatymo ant atramos momentu, sumažejo atramos trukmè ir šlaunies lenkimo kampas statant koją ant atramos; patikimai padidèjo didesnio meistriškumo sportininkių bègimo greitis, žingsnio ilgis bei maksimalus šlaunies tiesimo greitis atramos metu, sumažejo atramos trukme ir šlaunies lenkimo kampas mosto pirmyn metu.

Gauti rezultatai rodo, kad bėgimo palengvintomis sąlygomis poveikis technikai priklauso nuo sportininkų meistriškumo. Tai galètu paaiškinti mūsu ir J. S. LeBlanc ir P. L. Gervais (2004) gautu tyrimo rezultatų skirtumus. J. S. LeBlanc ir P. L. Gervais (2004) tyrè šešis universiteto studentus: vieną moterị ir penkis vyrus, turinčius tam tikrą bėgimo palengvintomis salygomis ir bėgimo su pasipriešinimu patirti (jų maksimalusis bėgimo greitis vidutiniškai siekè $9,40 \pm 0,68 \mathrm{~m} / \mathrm{s}$, o bėgimo palengvintomis sąlygomis $-10,04 \pm 0,77 \mathrm{~m} / \mathrm{s}$ ).

Teigiamą bègimo palengvintomis sąlygomis poveiki galima pastebèti lyginant mūsų tiriamujų bejgimo pokyčius ir elito sprinterių bejgimo kinematinius rodiklius. G. P. Bruggeman ir B. Gland (1990) duomenimis, elito vyrų sprinteriu, bėgančių 10,2-11,6 m / s greičiu, atramos trukmè svyruoja nuo 85 iki $95 \mathrm{~ms}$, moteru, bėgančiu $8,70-$ 9,09 m/s greičiu - nuo 95-108 ms. Mūsų tiriamujų, bėgančių tiek $6,88 \pm 0,38 \mathrm{~m} / \mathrm{s}$, tiek $8,21 \pm 0,61 \mathrm{~m} / \mathrm{s}$ greičiu, atramos trukmé buvo vienoda $-110 \pm 10 \mathrm{~ms}$, tačiau padidejjus sportininkių greičiui iki 7,65 $\pm 0,53$ ir 9,21 $\pm 0,68 \mathrm{~m} / \mathrm{s}$ (tempiant guma) atramos trukmé atitinkamai sumažèjo iki $100 \pm 10$ ir $90 \pm 20 \mathrm{~ms}$. Bègant palengvintomis sąlygomis, nustatyta atramos trukmès 
mažèjimo tendencija, ir šie duomenys sutinka su kitų autorių (Kivi et al., 2002) gautaisiais - didejjant bėgimo greičiui, mažèja atremties trukmè, tačiau lieka neaišku, ar šis pratimo poveikis išlieka bėgant natūraliomis sąlygomis.

D. E. Deshon ir R. C. Nelson, (1963), H. Kunz ir D. A. Kaufmann (1981), R. Mann ir J. Herman (1985) teigia, kad didelio meistriškumo sprinteriai, statydami pėdą ant atramos arčiau MC projekcijos, gali anksčiau pradèti aktyviai tiesti šlauni, sumažinti amortizacijos fazę ir neigiamą greičio pokyti (Mero, 1988). Atlikto tyrimo metu tempiant sportininkes standžia guma, patikimai sumažejo šlaunies lenkimo kampas atramos pradžioje. Manome, kad bėgant palengvintomis sąlygomis sportininkès yra skatinamos statyti pėdą arčiau MC projekcijos.

Daugelis autorių pabrěžia, kad šlaunies tiesimo greitis turi įtakos maksimaliajam bėgimo greičiui. Nustatyta, kad kuo didesnis pedos judejjimo horizontalusis greitis statant koją ant atramos, tuo mažesnis kūno MC greičio neigiamas pokytis (Lehmann, Voss, 1998). M. Čoh ir A. Dolenec (2002) atlikta Slovėnijos nacionalinès rinktinès sprinteriu technikos analizè parodè, kad greičiausios bègikès pèdos judejjimo greitis statant koją ant atramos buvo didžiausias. A. Ito ir M. Suzuki (1992) nustatė stiprų koreliacini ryšs $(r=0,78)$ tarp šlaunies tiesimo greičio atremties fazeje ir vyru sprinteriu bègimo greičio. Šio autoriaus duomenimis, šlaunies tiesimo greitis sieke 13,95 rad/s, moteru šis rodiklis mažesnis ir svyruoja nuo 8,72 iki 10,47 rad / s (Lehmann, Voss, 1998; Čoh, Dolenec, 2002). Mūsų tirtų mažesnio meistriškumo bègikių maksimalusis šlaunies tiesimo greitis bègant palengvintomis sąlygomis siekè 8,62 $\pm 0,9 \mathrm{rad} / \mathrm{s}$, didesnio meistriškumo $-10,43 \pm 0,5 \mathrm{rad} / \mathrm{s}$, ta- čiau šis greitis pasiekiamas ne kojos pastatymo momentu, o atremties viduryje arba pabaigoje. Taigi būtų galima teigti, kad bėgimas palengvintomis sąlygomis nekeičia bėgimo technikos, nes vienas iš pagrindiniu sprinto bėgimo technikos elementu išlieka nepakitęs, tačiau analizuojant individualius kinematinių rodiklių pokyčius galima pastebėti, kad didejant šlaunies tiesimo greičiui atremties pradžioje, maksimalusis šlaunies tiesimo greitis šiek tiek sumažeja.

\section{IŠVADOS}

Lyginant skirtingo meistriškumo sportininkių bėgimo kinematinius rodiklius bėgant maksimaliuoju greičiu natūraliai ir bėgant palengvintomis salygomis (tempiant guma), buvo nustatyti statistiškai patikimi šių rodiklių pokyčiai:

- patikimai padidejo mažesnio meistriškumo sportininkių bėgimo greitis, bėgimo tempas, žingsnio ilgis ir šlaunies tiesimo greitis kojos pastatymo ant atramos momentu, sumažèjo atramos trukmé bei šlaunies lenkimo kampas statant koją ant atramos;

- patikimai padidejo didesnio meistriškumo sportininkių bègimo greitis, žingsnio ilgis ir maksimalusis šlaunies tiesimo greitis atramos metu, sumažejo atramos trukmẻ ir šlaunies lenkimo kampas mosto pirmyn metu.

Šlaunies kampinio judèjimo analizè leido pastebèti, kad didesnio meistriškumo sprinterèms palengvintų bėgimo sąlygų taikymas neturejjo reikšmingos įtakos labiausiai greitị limituojančiam bėgimo technikos elementui — šlaunies tiesimo greičiui kojos pastatymo ant atramos momentu.

\section{LITERATŪRA}

Bruggemann, G. P., Gland, B. (1990). Time analysis of the sprint events. Scientific research project at the game of the XXXIV Olympiad - Seoul 1988 - final report. New Studies in Athletics (Suppl.).

Corn, R. J., Knudson, D. (2003). Effect of elastic-cord towing on the kinematics of the acceleration phase of sprinting. The Journal of Strength and Conditioning Research, 17 (1), 72-75.

Čoh, M., Dolonec, A. (2002). Kinematic, kinetic and electromyographic characteristics of the sprinting stride of elite female sprinters. In M. Čoh (Ed.), Application of Biomechanics in Track and Field (pp. 19-33). Ljubljana: Institute of Kinesiology, Faculty of Sport, University of Ljubljana.

Deshon, D. E., Nelson, R. C. (1963). A cinematographical analysis of sprint running. Research Quarterly, 35, $451-455$.
Ito, A., Suzuki, M. (1992). The men's 100 meters. New Studies in Athletics, 4, 47-52.

Johson, M. D., Buckley, J. G. (2001). Muscle power patterns in the mid-acceleration phase of sprinting. Journal of Sport Science, 19 (4), 263-272.

Kivi, D. M. R., Maraj, B. K. V., Gervais, P. (2002). A kinematic analysis of high speed treadmill sprinting over a range of velocities. Medicine and Science in Sports and Exercise, 34, 662-666.

Knicker, A. (1997). Neuromechanics of sprint specific training skills. In J. Wilkerson, K. Liudwig \& W. Zimmermann (Eds.), Biomechanics in Sports XV (pp. 17-21). Denton, TX: Texas Woman's University Press.

Kunz, H., Kaufmann, D. A. (1981). Biomechanical analysis of sprinting. Decathletes versus champions. British Journal of Sports Medicine, 15, 177-181. 
LeBlanc, J. S., Gervais, P. L. (2004). Kinematics of assisted and resisted sprinting as compared to normal free sprinting in trained athletes. In M. Montagne, D. G. Robertson, and H. Sveistrup (Eds.), Proceedings of XXII International Symposium on Biomechanics in Sports (pp. 536). Ottawa: University of Ottawa.

Lehmann, F., Voss, G. (1998). Innonationen fur den Sprint und Sprung ,ziehende“ Gestaltung der Stutzphasen - tiel 2. Leistungssport, 1, 18-22.

Mann, R. (1981). A kinetic analysis of sprinting. Medicine and Science in Sports and Exercise, 13, 325-328.

Mann, R., Herman, J. (1985). Kinematic analysis of Olympic sprint performance: Men's 200 meters. International Journal of Sport Biomechanics, 1, $151-162$.
Mann, R., Sprague, P. G. (1980). A kinetic analysis of the ground leg during sprint running. Research Quarterly for Exercise and Sport, 51 (2), 334-348.

Mero, A. (1988). Force-time characteristics and running velocity of male sprinters during the acceleration phase of sprinting. Research Quarterly, 59 (2), 94-98.

Mero, A., Komi, P. V. (1987). Electromyographic activity in sprinting at speeds ranging from sub-maximal to supramaximal. Medicine and Science in Sports and Exercise, 19 (3), 266-274.

Satkunskienè, D., Stanislovaitis, A. (2004). Pasaulio ir Lietuvos elito sprinterių bėgimo žingsnio kinematinių charakteristiku palyginamoji analizè. Sporto mokslas, 1, $6-13$.

Wood, A. (1987). Biomechanical limitations to sprint running. Medicine and Sport Science, 25, 58-71.

\title{
EFFECT OF ASSISTED SPRINTING ON KINEMATIC VARIABLES IN SPRINT RUNNING OF DIFFERENT SKILLED ATHLETES
}

\author{
Danguolè Satkunskiené $\dot{e}^{1,2}$, Donatas Rauktys ${ }^{2}$ \\ Kaunas University of Technology ${ }^{1,2}$, Lithuanian Academy of Physical Education ${ }^{2}$, \\ Kaunas, Lithuania
}

\begin{abstract}
The purpose of this study was to examine the kinematics of sprint running of different skilled athletes under assisted conditions as compared to normal sprinting during top-speed phase of a sprint.

Six volunteer female subjects: three expert sprinters (age 20-26 years; $200 \mathrm{~m}$ result $23.86-25.33 \mathrm{~s}$ ) and three lower level sprinters (age 13-15 years; 27.54-27.68 s respectively) completed 3 trials in different conditions: free sprinting at sub-maximal running speed and assisted sprinting at supra-maximal running speed. Two full strides were analyzed with one video camera filming the performers in the sagittal plane; 50 pictures per second were recorded. Contact time, flight time, the angle of tight relative to the vertical axis were obtain from the video recording by using 4-points, 3-segment leg model with SIMI MOTION 2D software. Stride length and rate, angular displacement and velocity of thigh were calculated.

Statistical analysis found significant $(\mathrm{p}<0.05)$ differences between assisted and normal sprinting for average running speed, stride length, contact time, max angular velocity of thigh during support phase independent of athletes' skill. Assisted sprinting significantly decreased the angle of max thigh flexion angle in the leg recovery phase for expert sprinters (from $64.62 \pm 4$ to $59.27 \pm 3.2^{\circ}$ ); increased thigh angular velocity at the start of support phase (from $4.70 \pm 0.78$ to $6.40 \pm 1.3 \mathrm{rad} / \mathrm{s}$ ) and decreased thigh angle at the start of support phase (from $31.39 \pm 4$ to $27.35 \pm 2.6^{\circ}$ ) for lower level sprinters. Comparison of individual curves of thigh angular displacement and angular velocity under assisted and normal sprinting condition showed that changes of kinematic variables of sprinting stride not always reflect changes in sprinting technique as particular motor pattern.

Further research is needed to clarify the effect of assisted sprinting as training techniques to improve sprint performance.
\end{abstract}

Keywords: sprinting, kinematics, assisted sprinting, skill.

Gauta 2006 m. rugsèjo $1 \mathrm{~d}$.

Received on September 1, 2006

Priimta 2006 m. gruodžio $6 \mathrm{~d}$.

Accepted on December 6, 2006
Danguolè Satkunskienè

Kauno technologijos universitetas

(Kaunas University of Technology)

Mickevičiaus g. 37, LT-44244 Kaunas

Lietuva (Lithuania)

Tel +37068617424

E-mail danguole.satkunskiene@ktu.lt 